\title{
Urethral caruncle in a young pregnant woman: an uncommon cause of urethral overgrowth
}

\section{Shailja Chauhan, Vikas Sharma, Vikram K. Mahajan}

\author{
Department of Dermatology, Venereology \& Leprosy, Dr. R. P. Govt. Medical College, Kangra (Tanda)-176001 (Himachal \\ Pradesh), India
}

Corresponding author: Dr. Vikram K Mahajan, E-mail: vkm1@rediffmail.com

Sir,

Urethral caruncle is a benign fleshy overgrowth arising from the mucosa of posterior lip of distal urethra affecting postmenopausal women more often than premenopausal or perimenopausal women and men [1,2].

A 23-year-old woman in $9^{\text {th }}$ month of her second pregnancy was referred from surgery clinic for evaluation of a hematoma-like mass protruding in the vaginal introitus. She had consulted at a peripheral centre for urinary frequency, dysuria and one episode of mild hematuria 2 weeks back. She was treated as a case of infected hematoma with amoxiclavunate $625 \mathrm{mg}$ three times daily for 5 days without benefit. Her first pregnancy/parturition and postpartum period 3 years back, and medical history were unremarkable. She had no lower abdominal pain or vaginal discharge and antenatal examination was normal. Genitourinary examination showed solitary, fleshy, painless, brownishblack, soft to firm sessile mass with uneven lobulated surface arising from posterior lip of the urethra and protruding in the anterior introitus (Fig. 1). No excoriations, bleeding, or ulceration/crusting were noted. She did not consent for biopsy. With a diagnosis of urethral caruncle she was counselled about its benign nature, advised Sitz bath and follow up after delivery.

The exact etiopathogenesis of urethral caruncle remains obscure and its development is imputed to distal urethral prolapse due to urogenital atrophy from estrogen deficiency. The possible role of autoimmunity remains uncertain [3]. Chronic irritation of the exposed urethral mucosa only contributes to the growth, hemorrhage, and necrosis of the lesion. Clinically, it usually appears as a small to about $1 \mathrm{~cm}$ sized pink or reddish mass at the urethral meatus while purple or black color indicates thrombosis. When present in premenopausal women it may enlarge during pregnancy. Being mostly asymptomatic it is usually a chance finding during pelvic examination. However, pain, and dysuria may occur and few patients may seek consultation for bleeding from the lesion after noticing staining of undergarments. Urinary retention has been reported but storage or voiding abnormalities are not observed in urodynamic studies [4]. Tumors occur in about $2 \%$ of urethral caruncles and intraepithelial squamous cell carcinoma has been reported arising within the urethral caruncle [5]. The diagnosis is clinical but histopathological features of granulation tissue covered by either mixed hyperplastic urothelial, squamous or transitional epithelium infolding into papillary architecture, stromal fibrosis, edema, and/or inflammation will differentiate it from other simulating lesions of urethral melanoma, tuberculosis, intestinal ectopia, lymphoma, and urethral leiomyoma $[1,6,7]$. Urinalysis will exclude urinary tract infection and cystoscopy may be needed to ascertain origin of hematuria or to diagnose bladder and urethral abnormalities such as urethral prolapse, carcinoma, diverticulum, or periurethral abscess.

Most cases are treated conservatively with warm Sitz baths and topical estrogen creams or anti-inflammatory drugs despite their uncertain efficacy. Excisional biopsy is only needed for enlarging or large symptomatic lesions, atypical morphology, failure of conservative treatment, or when the diagnosis is uncertain.

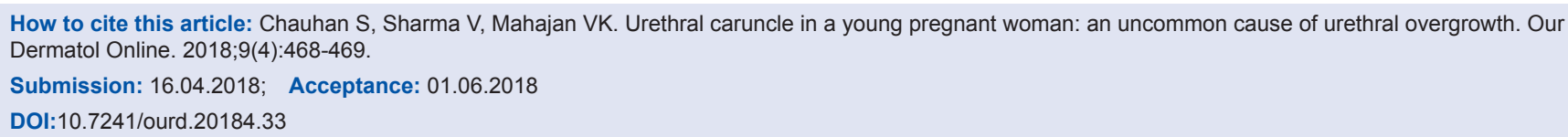




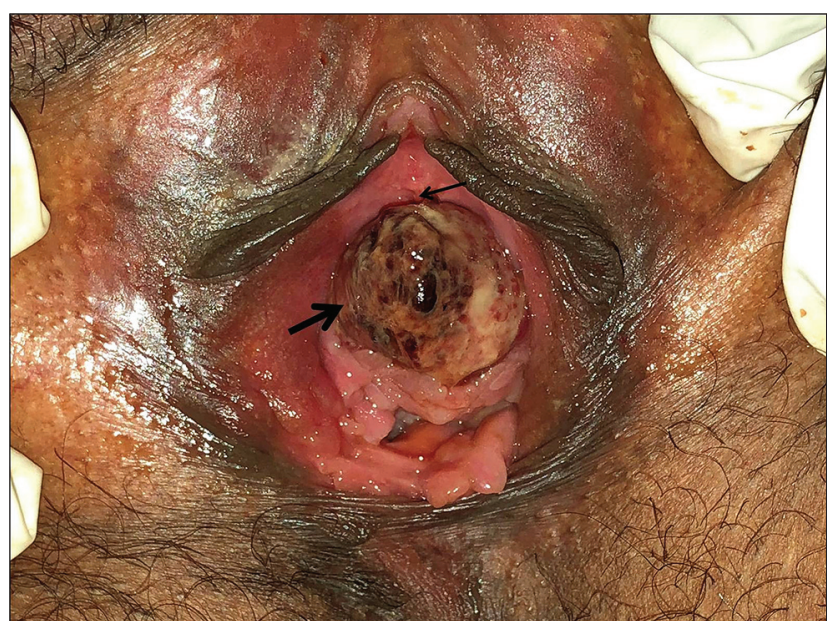

Figure 1: A solitary, fleshy, sessile mass in the anterior introitus (thick arrow) sized about $2 \times 1 \mathrm{~cm}$ with lobulated uneven surface around lower part of urethral meatus (thin arrow). The brownish-black color is because of thrombosed vessels.

\section{CONSENT}

The examination of the patient was conducted according to the Declaration of Helsinki principles.

\section{REFERENCES}

1. Conces MR, Williamson SR, Montironi R, Lopez-Beltran A, Scarpelli M, Cheng L. Urethral caruncle: clinicopathologic features of 41 cases. Hum Pathol. 2012;43:1400-4.

2. Karthikeyan K, Kaviarasan PK, Thappa DM. Urethral caruncle in a male: a case report. J Eur Acad Dermatol Venereol. 2002;16:72-3.

3. Williamson SR, Scarpelli M, Lopez-Beltran A, Montironi R, Conces MR, Cheng L. Urethral caruncle: a lesion related to IgG4associated sclerosing disease? J Clin Pathol. 2013;66:559-62.

4. Ozkurkcugil C, Ozkan L, Tarcan T. The effect of asymptomatic urethral caruncle on micturition in women with urinary incontinence. Korean J Urol. 2010;51:257-9.

5. Kaneko G, Nishimoto K, Ogata K, Uchida A. A case of intraepithelial squamous cell carcinoma arising from urethral caruncle. Can Urol Assoc J. 2011;5:E14-6.

6. Chen YR, Hung LY, Chang KC. Mucosa-associated lymphoid tissue-type lymphoma presenting as a urethral caruncle with urinary bladder involvement. Int J Urol. 2014;21:1073-4.

7. Saroha V, Dhingra KK, Gupta P, Khurana N. Urethral leiomyoma mimicking a caruncle. Taiwanese J Obstet Gynecol. 2010;49:523-4.

Copyright by Shailja Chauhan, et al. This is an open-access article distributed under the terms of the Creative Commons Attribution License, which permits unrestricted use, distribution, and reproduction in any medium, provided the original author and source are credited.

Source of Support: Nil, Conflict of Interest: None declared. 